\title{
Introduction: a world of parliamentary relations? Parliamentary cooperation and diplomacy in EU external relations
}

\section{Kolja Raube, Jan Wouters and Meltem Müftüler-Baç}

In today's increasingly complex and interdependent world, the role of parliaments remains a relatively understudied research topic. The multiple patterns of global governance are mostly dominated by the executive branches of government, with parliaments remaining on the sidelines. Anne-Marie Slaughter in her work A New World Order (2004) described the global order as a network of transgovernmental network relations. At the same time, she noted the role of parliaments in networked globalism. Her analysis concluded that parliaments lack the ability and interest to network with other parliaments in the world, and essentially run behind the advanced governmental interplays that effectively shape global governance. Through the prism of current research on parliamentary cooperation in the European Union (EU), the present volume aims to revisit Slaughter's perspective (see also Janèiæ 2015). At the same time, this volume obviously adds to the literature of European foreign policy, which so far has treated parliamentary activity and relations in the EU's external relations rather as an afterthought. Only lately has attention shifted towards an increased role of the European Parliament (EP) and national parliaments, especially with regard to international agreements and trade policy (Rippoll Servent 2014; Rosén and Raube 2018; Wouters and Raube 2018; Woolcock 2012).

Research on parliamentary cooperation shows the increasing networking of parliaments not only in the EU (Crum and Fossum 2009; Lupo and Fassone 2016) but also between the EU and actors outside the EU (see Costa and Dri 2014; Jančić and Stavridis 2016). This volume also focuses on comparative examples of parliamentary cooperation of actors and organizations outside the EU. Overall, it not only sheds light on EU parliamentary cooperation, but also on the scope and role of parliamentary networks in an increasingly interdependent world. As such it aims to make a contribution to both the global governance and EU external relations discourses by highlighting the role of parliaments. 


\section{THE TREATY OF LISBON AND PARLIAMENTARY COOPERATION: INTER-PARLIAMENTARY COOPERATION AND DIPLOMACY IN EU EXTERNAL RELATIONS}

The Treaty of Lisbon has given a boost to the role of national parliaments in contributing to the 'good functioning of the European Union' (Article 12 TEU; see also Fromage 2015, 2016), the role of the European Parliament in general and in the EU's external relations in particular (Article 14; Article 218 TEU), as well as inter-parliamentary cooperation between the European Parliament and national parliaments within the EU (Article 12(f) TEU) (Fromage and Raube 2018). The greater role that the European Parliament now plays in EU external action (Corbett 2012; Raube 2012; Ripoll Servent 2014; Rosén 2015; Rosén and Raube 2018; Woolcock 2012) is emphasized not only in terms of legislating, budgetary control and executive accountability, but also in view of its external relations through a tight network of parliamentary delegations and other parliamentary action in third countries (Jančić and Stavridis 2016). At the same time, national parliaments and the European Parliament cooperate across levels of governance in the field of EU external action in order to exchange information (Wouters and Raube 2016), not least through interparliamentary meetings and the newly established Interparliamentary Conference on CFSP/CSDP (IPC CFSP) (Herranz-Surrallés 2014; Raube and Wouters 2017; Wouters and Raube 2012).

The phenomenon of parliamentary cooperation - inter-parliamentary cooperation between national parliaments and the EP in the EU (Article 12 TEU; Protocol 1, Article 9 ff. TEU) and diplomacy of parliaments in EU external action (Stavridis 2002; Weisglas and de Boer 2007) - is a relatively new object of research (Kraft-Kasack 2008). Scholarship in the field has only started to emerge with a number of important publications regarding inter-parliamentary cooperation within the EU and European Parliament diplomacy in the context of EU external action (Lupo and Fasone 2016; Jančić and Stavridis 2016; Malamud and Stavridis 2011; Marschall 2008; Petrova and Raube 2016; Peters et al. 2010; Stavridis and Irrera 2015; Wouters and Raube 2016).

This volume will look at these different developments by analysing parliamentary cooperation and diplomacy both at the EU level and within other European and international organizations. The aim is hence to look at the internal and external dimension of parliamentary cooperation and situate it in the context of EU external relations. 


\section{INTER-PARLIAMENTARY COOPERATION AND DIPLOMACY: TO WHAT END?}

The study of inter-parliamentary cooperation and diplomacy in the context of EU external relations carries meaningful insights for policy making in EU external relations. Overall, there is a need to assess various forms of interparliamentary cooperation through multiple empirical case studies. In other words, to what end do parliaments cooperate?

First, while governments increasingly take decisions on the European level, inter-parliamentary cooperation is based on parliamentary needs to exchange information and - if possible - to arrive at mutual understandings (see also Wagner, this volume). In other words, national parliaments and the European Parliament can create network relations in order to attract information about governance decisions that they otherwise would not be able to obtain on the European or national level (Peters et al. 2010). While such networks may seem logical in terms of asymmetrical information sharing in EU external policies, it is important to point out some of the challenges that inter-parliamentary cooperation and diplomacy may face. The first is related to the overburdened agenda of Members of the European Parliament (MEPs) and national parliamentarians to attend and travel either across Europe or the world to attend the various meetings (Wouters and Raube 2016). There is a proliferation in the number and size of inter-parliamentary (IPC) meetings, as far as both standing bodies and ad hoc events are concerned. In research that was conducted earlier, a 'fatigue' of inter-parliamentary cooperation was clearly evident in that regard (Wouters et al. 2014). IPC fatigue may result in decreasing attendance rates, lack of preparation and debriefing by participating parliaments, etc. Moreover, what may be a humble objective of the treaties - the cooperation of parliaments across levels of governance - is often linked to the parliaments' struggles to recognize each other's competences in the field. The example of the IPC on CFSP/CSDP is an illustrative one, where MEPs and national parliamentarians had a difficult time agreeing on the set-up of the conference due to the different interpretations of competences (Herranz-Surrallés 2014).

Second, inter-parliamentary cooperation in the EU can be seen in the light of a quest for more accountability in EU policy making at large (Cooper 2012; Crum and Fossum 2009) and scrutiny and control in EU external relations more specifically (Lord 2011; Wagner 2006; Wouters and Raube 2012, 2016). In the EU more generally, the cooperation of national parliaments and the European Parliament is seen as the emergence of a 'multi-level parliamentary field' that does contribute to the representation of EU citizens and democratic accountability in EU 
decision making (Crum and Fossum 2009). More specifically, while in EU external relations decision making remains fragmented and, depending on the external policy area, will follow supranational or intergovernmental decision-making logics, the roles of the European Parliament and national parliaments vary greatly (Peters and Wagner 2010). For example, in the field of CSDP scholars have pointed to double-democratic deficits on the European and national levels (Wagner 2006; Raube 2014). In that regard, the advent of the new IPC on CFSP has been seen as a potential arena not only to enhance the information of parliaments across levels on issues regarding CFSP/CSDP, but - moreover - as a contribution to potentially more scrutiny of decisions on the European and national levels (Wouters and Raube 2016). The empirical reality, however, as briefly mentioned above, also points to the competition and struggles of parliaments across the different levels (European Parliament and national parliaments) of the EU multi-level polity to come to terms with how such inter-parliamentary mechanisms could be set up and operated (Herranz-Surrallés 2014). In the end then what is the purpose of inter-parliamentary cooperation and its added value for EU decision making? How can it be justified? What are the obstacles and challenges that inter-parliamentary cooperation faces in EU external relations?

Third, when we look at parliamentary diplomacy (Stravridis 2002; Weisglas and de Boer 2007), researchers need to map and analyse various instruments of cooperation and parliamentary activity in the field of external relations. Scholarship has now started exploring the field (Jančić and Stavridis 2016). However, so far explorations have remained descriptive in nature. The Virtual Map of Parliamentary Cooperation (VIPCO 2018) contributes to the mapping of the various institutions and mechanisms. In fact, according to Article 3 of the 'Principles governing delegation activities' adopted by the Conference of Presidents on 21 September 2006, "delegation activities shall, on the one hand, be aimed at maintaining and enhancing contacts with parliaments of States that are traditionally partners of the European Union and, on the other hand, contribute to promoting in third countries the values on which the European Union is founded"; moreover, "parliament's international contacts shall be governed by the principles of public international law" and "parliament's international contacts shall be aimed at fostering, wherever possible and appropriate, the parliamentary dimension of international relations". Currently, the European Parliament contributes with more than 40 delegations to bilateral and multilateral parliamentary meetings worldwide, including, for example, the ACP-EU Joint Parliamentary Assembly and the interparliamentary assembly 'Euronest' in the EU's Eastern Partnership. 
Next to the standing delegations, one has seen the creation of a permanent 'Liaison Office' of the European Parliament to Washington DC and the travelling diplomacy of various MEPs to conflictual places, such as Ukraine. It is in the context of these increasingly networked relations between the EP and the outside world that we have to ask for parliamentary diplomacy's added value in the area of EU external relations. For example, while diplomatic activities between the EU and the rest of the world have been institutionalized by the Treaty of Lisbon by establishing EU delegations (Spence and Batora 2015), it becomes a pertinent question whether these delegations can manage to project the EU's image, norms, rule and principles in third countries on their own. While public diplomacy and mediation efforts become ever more important instruments in the EU's external promotion of its own values - such as democracy, human rights and the rule of law (Raube et al. 2016) - bilateral and multilateral parliamentary diplomacy between the EP and third countries and regions bears the potential to become a complementary element of EU external action and diplomacy. In other words, EP diplomatic action would not be seen as competing with, but rather as complementing the wider spectrum of diplomatic activities. Still, we need to ask ourselves whether the European Parliament is conducting parliamentary diplomacy on its own behalf or whether it is advocating the official position of the EU in external action. If the latter were true, what remains of the complementary added value that the European Parliament could bring in when dealing with third parties?

\section{COMPARING PARLIAMENTARY COOPERATION IN EU EXTERNAL RELATIONS}

This volume focuses on the EU's external relations and parliamentary cooperation within. Its focus is primarily on the EU. However, the volume also aims to situate the findings in a comparative perspective, and engages in a debate that goes beyond the EU, specifically uncovering the EU's relations not only with its neighbourhood, but also intra-institutional cooperation among different international institutions outside the EU. As such, the volume looks into different concentric circles of parliamentary cooperation, with the EU based at the heart of the circles.

Through its comparative perspective, this volume situates the EU's internal and external dimension of parliamentary cooperation in a wider context of parliamentary cooperation, including the cooperation of other states and international organizations. What are other examples of parliamentary cooperation in other regions and countries, bilateral or 
multilateral, and how can we explain their rise and practice? Providing answers to these questions, the book will hence be able to show the current research of EU parliamentary cooperation in EU external action in a wider global context, filling an existing theoretical and empirical gap in the current literature.

\section{WHICH OBJECTIVES GUIDE THE STUDY OF PARLIAMENTARY COOPERATION AND DIPLOMACY?}

As mentioned above, the aim of this volume is to cover the numerous dimensions of parliamentary cooperation and diplomacy in Europe and beyond:

- first, inter-parliamentary cooperation in European organizations and the EU, as well as parliamentary cooperation in other regional and international organizations;

- second, parliamentary diplomacy between the EU and third countries, as well as the parliamentary diplomacy of other parliaments in other regions of the world.

By focusing on these two dimensions, the volume sheds light on and helps explain the workings of parliamentary cooperation in other regional organizations around the world, as well as the practice of parliamentary diplomacy of the other actors outside the EU.

While the two dimensions of parliamentary cooperation - interparliamentary cooperation and parliamentary diplomacy - are conceptualized in multiple ways throughout the volume, the book offers a comprehensive overview of the different theoretical accounts and the realities in the field, channels, fora and policy fields of inter-parliamentary cooperation and parliamentary diplomacy. In the following, we introduce the various conceptualizations and empirical perspectives.

\section{Parliamentary Cooperation and Diplomacy in EU External Relations: Conceptions and Theoretical Approaches}

Conceptualizations and theoretical accounts should provide a comprehensive insight into the current theoretical and multi-disciplinary accounts of European integration research, European external relations and international relations. More specifically, theoretical approaches such as new institutionalism and inter-institutional cooperation 
(Christiansen 2001); multi-level governance and democratic accountability, scrutiny and control (Marks et al. 1996; Curtin et al. 2010); various conceptions of European foreign and security policy, including normative power (Manners 2006); transnational relations and actors in the EU (DeBardeleben and Hurrelmann 2011) - can provide research angles that help to describe and explain parliamentary cooperation. While on the one hand it will be analysed how the concept of the multi-level parliamentary field fits with EU external relations and, hence, whether it can serve as a meaningful concept in this domain as well (see chapter by Fossum and Rosén, this volume), it will also be explained how institutional approaches can be made use of to explain parliamentary cooperation (chapter by Christiansen and Groen) and how the rise of regional parliamentary institutions can be explained (chapter by Lenz). At the same time, specific attention will also be given to transnationalism as an approach of added value and the different rationales that underpin parliamentary cooperation (chapter by Fonck and Raube; chapter by Wagner).

\section{Inter-Parliamentary Cooperation and Diplomacy Arenas in EU External Relations}

This part of the book will focus on the various inter-parliamentary cooperation arenas in the EU in general, in EU external relations more specifically and in other organizations such as NATO. The idea of the chapters here is to show the variations of institutional frameworks and practices of the inter-parliamentary committees, conferences and so-called international parliamentary institutions (IPIs) (see Cutler 2001; Malamud and Stavridis 2011). Not only will similarities and differences offer us meaningful insights about the specific differences of inter-parliamentary cooperation in external relations across policies and organizations (chapters by Cutler and von Lingen and by Selden and Oehman), but they will also help answer questions of why they are constituted in the first place (chapter by Cooper; chapter by Peters), and what the specific role is for the European Parliament when it engages in parliamentary cooperation (chapter by Fromage) and how the new IPC CFSDP not only impacts parliaments but also policy making in the field of CFSP (chapter by Stavridis and Gianniou). Moreover, from a foreign policy perspective, Lord analyses the specialty of inter-parliamentary cooperation in the security domain, before concluding with a normative conception of how much parliamentary cooperation is needed to arrive at accountable and legitimate EU external relations. 


\section{Inter-Parliamentary Cooperation and Diplomacy in the EU's Neighbourhood}

In many ways, the EU's neighbourhood policy is a litmus test for the rest of the EU's foreign policy. Given the proximity of the EU's neighbours, the EU has a special interest in the region, its economic markets and political stability. However, over recent years, the EU has been witnessing the rise and failure of the Arab Spring, an assertive and expansionist Russian foreign policy in the East, and the increasingly difficult relationship with the Turkish government. With these developments, many challenges and crises emerged; e.g. the refugee/migration crisis and challenges posed for finding cooperative arrangements with countries under the Eastern Partnership such as Ukraine and Moldova. This part of the book focuses on the role of parliamentary cooperation in these increasingly difficult circumstances with the countries in the EU's periphery. The chapters follow especially the various fora of existing parliamentary relations between the European Parliament and parliaments of EU neighbouring countries. These chapters focus on EU-Turkey parliamentary relations in general, and more specifically in view of the Syrian crises (chapters by Gürkan and by Demirsu and Müftüler-Baç), and the specific input of the EU-Turkey Joint Committee and the EU-Ukraine Parliamentary Association Committee on the relations of the EU with its partners (chapter by Wodka and Ciancara). Another aspect examined in this part is the specific role of the European Parliament as a normative actor and agenda setter in the neighbourhood (chapters by Glahn and by Góra), while special attention is given to the European Parliament's efforts in conflict mediation in the region (chapter by Fonck).

\section{Multilateral Parliamentary Cooperation and Diplomacy in EU External Relations and Beyond}

In this part, the various chapters look at standing multilateral parliamentary cooperation with other regions of the world, including Latin America (chapters by Müller and Moure), Asia (chapter by Nuttin) and Africa (chapter by Delputte and Williams). The section also brings in the comparative perspective by focusing on other regional parliamentary cooperation fora in Europe and beyond, including the Economic Community of West African States/ECOWAS (chapter by Belley), the Western Balkans (chapter by De Vrieze) and the post-Soviet space (chapter by Petrova). The insights of these chapters are twofold: on the one hand they demonstrate the state of the art regarding the European Parliament's involvement in multilateral parliamentary cooperation fora, 
while at the same time showing that parliamentary cooperation clearly is anchored in other regions and fora. This potentially confirms the thesis of a 'globalized multi-layered parliamentarism' (Jančić 2015). The question arises as to which degree such parliamentarism may or may not be different to the one promoted by the European Parliament, and for what reasons.

\section{Parliamentary Diplomacy Issue Areas: Trade, Environment and International Conflict}

This section focuses on the European Parliament's actorness in EU external relations and its contribution to and impact on EU external relations. The variation across policy areas allows us to show differences in parliamentary involvement and cooperation: from trade (chapters by Yan and by Jančić) to the environment (chapter by Biedenkopf) and international conflict (chapter by Redei).

This volume would not have been possible without the contributions of each and every single author. The Jean Monnet Network on 'Interparliamentary Cooperation in the EU's External Action - Parliamentary Scrutiny and Diplomacy in the EU and Beyond' (PACO) during the years 2014-17 was a wonderful framework for colleagues conducting research on parliaments, parliamentary cooperation and diplomacy in Europe and beyond. We hope that this volume will contribute to the ongoing and growing debate on inter-parliamentary cooperation.

\section{REFERENCES}

Christiansen, T. (2001) Intra-institutional politics and inter-institutional relations in the EU: towards coherent governance? Journal of European Public Policy. 8(5), 747-69.

Cooper, I. (2012) A 'virtual third chamber' for the European Union? National parliaments after the Treaty of Lisbon. West European Politics. 35(3), 441-65.

Corbett, R. (2012) The evolving roles of the European Parliament and of national parliaments. In: Biondi, A., Eeckhout, P. and Ripley, S. (eds) EU Law after Lisbon. Oxford: Oxford University Press, pp. 248-61.

Costa, O. and Dri, C. (2014) How does the European Parliament contribute to the construction of the EU's interregional dialogue? In: Baert, F., Scaramagli, T. and Soderbaum, F. (eds) Intersecting Interregionalism: Regions, Global Governance and the EU. Dordrecht: Springer, pp. 129-50.

Crum, B. and Fossum, J.E. (2009) The multilevel parliamentary field: a framework 
for theorizing representative democracy in the EU. European Political Science Review. 1(2), 249-71.

Curtin, D., Mair, P. and Papadopoulos, Y. (2010) Positioning accountability in European governance: an introduction. West European Politics. 33(5), 929-45.

Cutler, R. (2001) The emergence of International Parliamentary Institutions: New networks of influence in world society. In: Smith, G.S. and Wolfish, D. (eds) Who Is Afraid of the State? Canada in a World of Multiple Centres of Power. Toronto: University of Toronto Press, pp. 201-29.

DeBardeleben, J. and Hurrelmann, A. (eds) (2011) Transnational Europe: Promise, Paradox, Limits. London: Palgrave Macmillan.

Fromage, D. (2015) Les Parlements dans l'Union Européenne après le Traité de Lisbonne: Les Parlements Allemands, Britanniques, Espagnols, Français et Italiens. Paris: L'Harmattan.

Fromage, D. (2016) The second yellow card on the EPPO proposal: an encouraging development for Member States parliaments? Yearbook of European Law. 35(1), 5-27.

Fromage, D. and Raube, K. (2018) Les parlements des états membres dans une Union européenne en constante mutation. Politique Européenne. 59(1), 8-22.

Herranz-Surrallés, A. (2014) The EU's multilevel parliamentary (battle)field: inter-parliamentary cooperation and conflict in foreign and security policy. West European Politics. 37(5), 957-75.

Jančić, D. (2015) Globalizing representative democracy: the emergence of multilayered international parliamentalism. Hastings International and Comparative Law Review. 38(2), 197-242.

Jančić, D. and Stavridis, S. (2016) Special issue on parliamentary diplomacy in European and global perspectives. The Hague Journal of Diplomacy. 11(2-3).

Kraft-Kasack, S. (2008) Transnational parliamentary assemblies: a remedy for the democratic deficit of international governance? West European Politics. 31(3), 534-57.

Lord, C. (2011) The political theory and practice of parliamentary participation in the Common Security and Defence Policy. Journal for European Public Policy. 18(8), 1133-50.

Lupo, N. and Fasone, C. (eds) Interparliamentary Cooperation in the European Composite Constitution. Oxford: Hart.

Malamud, A. and Stavridis, S. (2011) Parliaments and parliamentarians as international actors. In: Reinada, B. (ed.) The Ashgate Research Companion to Non-State Actors. Farnham: Ashgate, pp. 101-15.

Marks, G., Hooghe, L. and Blank, K. (1996) European Integration since the 1980s: state-centric versus multi-level governance. Journal of Common Market Studies. 34(3), 343-78.

Marschall, S. (2008) Transnational parliamentary assemblies and european security policy. In: Peters, D., Wagner, W. and Deitelhoff, N. (eds) The Parliamentary Control of European Security Policy, RECON Report. Oslo: ARENA, pp. 109-32.

Peters, D. and Wagner, W. (2010) Between military efficiency and democratic legitimacy: mapping parliamentary war powers in contemporary democracies, 1989-2004. Parliamentary Affairs. 64(1), 175-92.

Peters, D., Wagner, W. and Deitelhoff, N. (2010) Parliaments and european security policy: mapping the parliamentary field. European Integration Online Papers 27. Vienna: European Community Studies Association, 16 August.

Petrova, I. and Raube, K. (2016) EuroNest: what drives inter-parliamentary 
cooperation in the Eastern Partnership? European Foreign Affairs Review. 21(1), $35-56$.

Raube, K. (2012) The European External Action Service and the European Parliament. The Hague Journal of Diplomacy. 7(1), 65-80.

Raube, K. (2014) Parliamentarisation approaches: parliamentary control in EU foreign policy. In: Wilga, M. and Karolewski, I.P. (eds) New Approaches to EU Foreign Policy. Abingdon: Routledge, pp. 125-41.

Raube, K. and Wouters, J. (2017) The many facets of parliamentary involvement and interaction in EU external relations. In: Jančić, D. (ed.) National Parliaments after the Lisbon Treaty and the Euro Crisis: Resilience or Resignation? Oxford: Oxford University Press, pp. 281-98.

Raube, K., Burnay, M. and Wouters, J. (2016) Introduction: the rule of law promotion as an external priority of the EU. Asia-Europe Journal. 14(1), 1-6.

Ripoll Servent, A. (2014) The role of the European Parliament in international negotiations after Lisbon. Journal of European Public Policy. 21(1), 568-86.

Rosén, G. and K. Raube (2018) Influence beyond formal powers: the parliamentarisation of European Union security policy. British Journal of Politics International Relations. 20(1), 69-83.

Slaughter, A.-M. (2004) A New World Order. Princeton: Princeton University Press.

Stavridis, S. (2002) Parliamentary Diplomacy: Some Preliminary Findings. Jean Monnet Working Papers in Comparative and International Politics. 48, University of Catania.

Stavridis, S. and Irrera, D. (eds) (2015) The European Parliament and its International Relations. Abingdon: Routledge.

VIPCO (2018) Virtual Map of Parliamentary Cooperation. Available from: https://ghum.kuleuven.be/ggs/research/paco/VIPCO (accessed 30 July 2018).

Wagner, W. (2006) The democratic control of military power Europe. Journal of European Public Policy. 13(2), 32-48.

Weisglas, W.F. and de Boer, G. (2007) Parliamentary diplomacy. The Hague Journal of Diplomacy. 2, 93-99.

Woolcock, S. (2012) European Union Economic Diplomacy: The Role of the EU in External Relations. Farnham: Ashgate.

Wouters, S. and Raube, K. (2012) Towards an interparliamentary scrutiny of CSDP. International Spectator. 47(4), 149-63.

Wouters, J., Beke, L., Chané, A., Hachez, N. and Raube, K. (2014) Enhancing cooperation between the European Parliament and EU national parliaments on EU human rights policy. European Parliament, Directorate-General for External Policies of the Union, EXPO/B/DROI/2013/20, March.

Wouters, J. and Raube, K. (2016) The Interparliamentary Conference on Common Foreign and Security Policy: a quest for democratic accountability in EU security governance. In: Lupo, N. and Fasone, C. (eds) Interparliamentary Cooperation in the Composite European Constitution. Oxford: Hart, pp. 227-45.

Wouters, J. and Raube, K. (2018) Rebels with a cause? Parliaments and EU trade policy after Lisbon. In: Santos Vara, J. and Sánchez-Tarberero, S.R. (eds) The Democratisation of EU International Relations through EU Law. London: Routledge, pp. 195-209. 